\title{
Denying Darwin: Views on science in the rejection of evolution by Dutch Protestants
}

Public Understanding of Science $0(0)|-| 1$

(C) The Author(s) 2012

Reprints and permission: sagepub.co.uk/journalsPermissions.nav DOI: 10.1 I77/09636625I2437328 pus.sagepub.com

@SAGE

\section{Peter Hildering}

Centrum Wiskunde \& Informatica (CWI), The Netherlands

\section{Luca Consoli and Riyan van den Born}

Radboud University Nijmegen, The Netherlands

\begin{abstract}
Evolution has met with considerable religious opposition for 150 years and is still controversial among various religious groups. This article tries to understand the evolution controversy by reframing it as a phenomenon of public understanding of science. Three paradigms were used as hypotheses for the rejection of evolution by Dutch Protestant Christians: knowledge deficit, attitude deficit and trust deficit. Ten Dutch Protestants rejecting evolution were interviewed about their views concerning evolution and science. It was found that the main reason for rejecting evolution was an a priori decision to trust the Bible more than science. Any views on science and evolution were based on this decision, so all three hypotheses, which suggest an a posteriori decision, were found to be not sufficient to explain the rejection of evolution, even though both a knowledge deficit and a trust deficit were found for some participants. However, all respondents felt that their a priori decision was supported by scientific facts. All respondents stated that evolution does not meet the criteria for good science and is therefore as unscientific as the belief in creation. Excluding evolution from science allows the respondents to retain their positive attitudes towards science.
\end{abstract}

\section{Keywords}

attitude deficit, creation, evolution, knowledge deficit, public understanding of science, trust deficit

\section{Introduction}

Since the day of its publication on 24 November 1859, the evolution theory of Charles Darwin has met with considerable opposition, notably from religious circles. Although scientific opposition decreased soon after, public rejection of evolution never died down. Recent research (Miller, Scott and Okamoto, 2006) shows that a substantial part of the western world does not accept the idea of

\section{Corresponding author:}

Luca Consoli, Institute for Science, Innovation, and Society, Faculty of Science, Radboud University Nijmegen, Heyendaalseweg I25, 6525 AJ Nijmegen, The Netherlands

Email: I.consoli@science.ru.nl 
evolution. The contrast between scientific and public acceptance of evolution, even 150 years after publication, is remarkable and calls for further research. The rejection of evolution is often linked with religious views. Research shows that individuals who hold a strong belief in a personal God and who pray frequently are significantly less likely to view evolution as "probably" or "definitely" true than adults with less conservative religious views (Miller et al., 2006). A study on the opinion of Brazilian university students about the themes of the origin of the universe and the evolution of life (De Souza et al., 2010) showed a direct relationship between the religious views of the student and the acceptance or rejection of evolutionary theory, with (non-Catholic) Christians being more likely to reject evolution than other students.

When looking at other controversies in which the public acceptance of scientific theories is at stake, the controversy surrounding evolution seems to stand apart. First, other contemporary controversies such as those surrounding genetically modified food, climate change and nanotechnology, focus on future risks for safety and/or health (Stankiewicz, 2009). This aspect is absent in the controversy concerning evolution. Secondly, the scientific consensus is almost unanimously in favour of evolution, and has been for nearly a century (National Academy of Sciences, 1998). While this might imply that the rejection of evolution is linked to the rejection of science as a whole, no correlation is found between the rejection of evolution and the rejection of other wellestablished scientific theories such as the causal relation between smoking and lung cancer, continental drift and the depletion of the ozone layer by CFC gases (De Souza et al., 2010). Therefore, it seems that the controversy concerning the public acceptance of evolution is a special case. It raises the question to what image of science do Christians who reject Darwin's theory of evolution subscribe. This paper aims to address this question.

Literature on the scientific views of Christians who reject evolution is scarce. There are qualitative studies focusing on public opinions on evolution (De Souza et al., 2010; Francis and Greer, 1999; Rutledge and Warden, 2000). Moreover, a lot of research has been devoted to the educational controversy in the United States regarding the teaching of evolution and creationism or intelligent design in public schools (i.e. Park, 2001; Pennock, 2004; Martin-Hansen, 2008; Rutledge and Warden, 2000). Quantitative studies in which the rejection of evolution by Christians is connected to images of science are also absent. As a Science Communication group, we want to bridge this gap, motivated by the Darwin Year 2009.

In order to explore the images of science of Christians who reject evolution we use the framework developed by Bauer, Allum and Miller (2007). In this paper, three main paradigms concerning the relation between science and the general public are distilled from 25 years of PUS research. Although there is an ongoing discussion between PUS scholars about the validity of these paradigms (i.e. Hess, 2011; Wynne, 1992), each of these paradigms has a distinct way of explaining and remedying the lack of support of the public for certain scientific results. They summarise the main approaches to science not accepted by the public, and therefore we will use these paradigms as hypotheses to explain the rejection of evolution by Christians.

- In the paradigm of scientific literacy, a lack of scientific knowledge (knowledge deficit) is assumed to be the cause of opposition to science and technology. The right education programme can remedy this deficit. Scientific knowledge is roughly divided into factual knowledge of scientific facts and terms and knowledge about the scientific method and scientific culture (Durant, 1993; Miller, 1998). Criticism of this paradigm focuses among others on pointing out that holding some core beliefs and values is not dependent on the level of scientific understanding (Slovic and Peters, 1998), and on the selection of appropriate measures of scientific understanding (Hayes and Tariq, 2000). 
- The public understanding of science (PUS) paradigm perceives a negative attitude (attitude deficit) towards science as the cause of opposition to science. The public needs to come into contact with science and learn to appreciate the achievements of scientific research. Criticism of this paradigm concentrates on similar issues to the paradigm of scientific literacy (see for example the charge of "institutional neuroticism" in Wynne, 1993).

- Finally, the paradigm of science and society does not blame the public for being ignorant or too negative, but science itself which has estranged itself from society. As a result, the public is no longer convinced of the integrity and reliability of the scientific community (trust deficit) (Wynne, 1992). Scientists have to try to regain trust by co-developing new technologies with society (Miller, 2001). As Bauer et al. (2007) note, there is a growing need to evaluate the effectiveness of this approach (Rowe and Frewer, 2004).

In this article, we will present our findings concerning the images of science of Christians who reject evolution, as understood from a public understanding of science framework. First we will outline the qualitative method used in our research, including the selection of respondents, the interviews and the interview analysis. Next we will show the results of the interviews with a focus on the three public understanding of science hypotheses. Finally, we will discuss the results and their implications for the evolution debate.

\section{Method}

The research question, namely what scientific views accompany the opposition to evolutionary theory, has not yet been addressed empirically. To get a deeper understanding of the personal beliefs about the relationship between science and religion, qualitative methods are used in order to give the respondents freedom to describe and explain their beliefs and views in their own words. In this section, the selection of the respondents, the structure of the interviews and the data analysis are described.

\section{Respondents}

To qualify as a respondent in this research, people had to be Dutch, Christian, aged above 18, and reject evolutionary theory. The research focused on Dutch Protestant Christians. Research shows that Roman Catholic Christians are less likely to reject evolution (De Souza et al., 2010; Pennock, 2004). Opinion polls in The Netherlands confirm this, and identify Protestants as the main affiliation of religiously motivated rejecters of evolution (De Hond, 2009; Synovate, 2009), especially Evangelicals and Reformed Christians (Calvinists). The respondent group should therefore at least contain members of these branches of Protestantism. Some background information about these specific groups for those not familiar with Dutch Protestantism should be in place here.

Dutch Calvinism is a conservative branch of Protestantism, putting emphasis on a rational understanding of the Christian faith. Besides the Bible, they consider three confessional documents to be the basis of their faith, namely the Heidelberg Catechism ("Heidelbergse Catechismus"), the Belgic Confession ("Nederlandse Geloofsbelijdenis") and the Five Points of Calvinism ("Dordtse Leerregels"). Dutch Reformed Christians are usually divided into two main groups: orthodox and bevindelijk. The orthodox gereformeerden put emphasis on the rational acceptance of grace, are more progressive and are usually associated with the political party ChristenUnie. The bevindelijk gereformeerden put emphasis on the existential experience of God's grace, are more conservative and are usually associated with the political party SGP (WRR, 2006). 
Dutch evangelicalism is a relatively new branch of Protestantism in The Netherlands and is heavily influenced by American evangelicalism. Dutch Evangelicals view the Bible as the absolute truth and put emphasis on a personal relationship with Jesus Christ, spiritual rebirth and spreading the message of Christ. The majority of Dutch Evangelicals are former members of other Dutch Protestant Churches (WRR, 2006).

For the selection of respondents a strategic non-representative sampling procedure was followed. "The objective of this approach is not to draw a statistically representative sample, but to obtain a wide range of variation in the responses through the strategic consideration of variables or factors expected to produce variation in the phenomenon being studied" (Gustafson, 2001: 8). In this study, age, gender, level of education and church affiliation were considered in the sampling process. For the higher educated respondents, it is taken into account whether they are educated in the natural sciences or not.

To recruit respondents for the interviews, a questionnaire was spread on several Dutch online discussion boards aimed at Christians. From all 257 respondents, 121 could be enlisted as Dutch Protestant Christian adults who opposed evolution. To fit into this group, respondents have to be self-reported adult Christians who visit a Christian communal service more than once a month and exercise a self-reported disbelief in evolution, denying at least that human beings share a common ancestor with apes. Twenty people of this group agreed to be contacted for an interview concerning their beliefs. From this group, eight respondents could be selected on the basis of the demographic variables described above, and were sent an interview invitation. The other twelve respondents shared too many demographic similarities (mainly young and high educated) with the others to be added to the group of candidates. Three people never replied to the invitation and an additional reminder, and no alternative candidates were available in the discarded group of twelve. Those five that did reply all agreed to an interview. Five additional people were recruited through snowballing and through personal contacts ${ }^{1}$ (Gustafson, 2001) to complete the group.

The research group consisted of five males and five females. The youngest respondent was 20 years old, the oldest 80 years. Three of them held a university degree in one of the natural sciences, two in another field of science, one attained higher education (hbo, hoger beroepsonderwijs), three attained mid-level education (mbo, middelbaar beroepsonderwijs) and one of them had no education beyond primary school. Five respondents were Reformed Christians (three of them orthodox gereformeerd and two of them bevindelijk gereformeerd), three were Evangelicals, one was a member of the Dutch Protestant Church and one respondent was a Jehovah's Witness.

\section{Interviews}

The respondents were interviewed individually by the first author in their own homes, except one, who was interviewed at the respondent's school. The interviews took approximately one hour. The interviews were semi-structured and consisted of four parts. Each part consisted of one or more initial questions on the topic discussed, and allowed the respondents to respond freely. For instance in the first part, which served as an introduction to the rest of the interview, the respondents were asked to give their motivation for rejecting evolution without further specification.

The second part was related to the knowledge deficit hypothesis and covered both factual scientific knowledge and knowledge about the scientific method. The respondents were asked about the role of scientific knowledge in their rejection of evolution; how they informed themselves on the subject of evolution and whether they thought obtaining scientific knowledge about evolution was important. To get an indication of their general knowledge about evolution, the respondents were asked to give a short summary of the theory of evolution in their own words. Although this does 
not give a thorough quantitative measure for the level of scientific knowledge of the respondents, the results could be used, along with other comments in the interview, to obtain an indication of the level of factual scientific knowledge. Finally, the respondents were asked for their knowledge about the scientific method in general and whether they thought research about evolution was scientific.

The third part of the interview was related to the attitude deficit hypothesis. The respondents were asked about their appreciation of science, namely what they thought about science in general, the way in which they involved themselves with science and what they thought about the contribution of science to society.

In the fourth part of the interview, relating to the trust deficit hypothesis, the respondents were asked for their trust in science and the scientific community.

\section{Analysis}

The interviews were digitally recorded and transcribed into the analysis tool Weft QDA (http:// www.pressure.to/qda/) for the purpose of analysing the data. In the first phase all data were ordered by labelling the fragments with codes that refer to the relevant analytical entries. In the structuring phase, emerging patterns and relations were identified and grouped, and all transcriptions were recoded through selective coding using these new labels (Wester and Peters, 2004).

\section{Results}

\section{Motivation for rejecting evolution}

The respondents unanimously identified their religious beliefs as the main reason for not believing in evolution. They view the Bible as the inspired Word of God, and they feel that the biblical account of creation is incompatible with the evolutionary account of the development of life on earth. Doubting one part of the Bible would ultimately lead to doubting the entire Word of God and is therefore unacceptable:

I always say: if I can't believe what is written in Genesis, why should I believe what is written about Jesus in the New Testament? If I can't trust one thing, can I trust something else? I think this strikes at the roots of faith. (R2)

Six of the respondents say they have little understanding for Christians who combine belief in evolution with their belief in God. They feel that belief in the biblical account of creation is essential to the Christian faith. All respondents named in addition to their religious motivation various scientific reasons for not believing in evolution. The argument most used, named by eight respondents, was that the evidence presented in favour of evolution merely supports socalled micro-evolution, evolution within the boundary of the species (or genera) created by God. Six respondents named positive arguments in favour of creation from creationism or intelligent design, and six argued for the scientific reliability of the Bible. Five of them named, spontaneously and independent from each other, a particular book called Moderne wetenschap in de Bijbel by Dutch author Ben Hobrink (transl. "Modern science in the Bible"), a book that argues that Old Testament laws and regulations demonstrate scientific facts that science has only recently discovered, and use it to support their claim that the Bible is a reliable source when it comes to science. 
Evolution is identified as being in conflict with the biblical message of creation. Since the respondents are convinced that the Bible contains the Word of God, any science in conflict with the Bible cannot be correct. This is where the decision to reject evolution takes place. Any scientific reasons are an addition to this decision, but follow after the initial decision not to believe evolution.

\section{The role of scientific knowledge}

No antipathy towards evolution and scientific knowledge concerning evolution was found among the respondents. All respondents have at some time in their lives actively searched for information concerning evolution. They were motivated either by interest in opinions different from their own, to learn scientific arguments for rejecting evolution or by the feeling that one needs to understand the subject that is rejected.

I chose deliberately to gain knowledge about evolution. I want to know how things work and what people mean. I know I cannot understand it in detail, but I try to understand the main themes. [...] It is important to study it, to be able to disprove it. (R10)

All respondents obtain most or part of their knowledge from Christian sources that aim to disprove evolution. Half of them also search for pro-evolution material. The factual scientific knowledge of evolution varied greatly between respondents. Three of the respondents, all of them highly educated, gave a fairly accurate description of the principles of natural selection, while the others merely described evolution in terms of the development from fish to rabbit to monkey and from monkeys to human beings. Common factual mistakes were considering Big Bang cosmology as part of the theory of evolution, naming fish or tadpoles as the first organisms to emerge and thinking that organisms evolve from small to big. Two of the respondents showed extensive knowledge of evolution, one of them having a Master's degree in biology and teaching biology, including evolution, in high school. This can be understood in the light of the reasoning described in the previous section. The decision to reject evolution is at first a non-scientific decision in which scientific knowledge plays no role. It is founded in the strong belief in a literal interpretation of the Bible. This pattern can be found in all the interviews; when the Bible is placed above science as a source of knowledge, no level of scientific knowledge can cause these Christians to believe in evolution. Scientific knowledge is first filtered by the Bible to determine whether it is acceptable. If it does not pass this test, it cannot be true. Respondents with a relatively high level of knowledge about evolution rejected evolution just as well as respondents with a low level of knowledge. A knowledge deficit concerning scientific knowledge about evolution therefore seems to be not a suitable explanation for the rejection of evolution.

On the subject of the scientific method, something interesting happened. While six of the respondents could accurately describe the scientific method all of the respondents, including those six, felt that evolution is not truly scientific. The argument used by all was that scientific knowledge concerning the past cannot be reproduced and is therefore never truly reliable.

Evolutionary science is fundamentally different from ordinary science. It is a historical science. Some people therefore say that it is not science at all, because you cannot reproduce the past. You can't experiment on the past to see if it will happen again. (R3) 
The past remains hidden. We can try to interpret the facts that we find, like fossils and strata. But every statement about the beginning ... you weren't there, you can't repeat it, so it is not science. (R4)

This line of reasoning was used regardless of level of education, involvement with the natural sciences or knowledge on the scientific method (by answering the question "What does it mean to study something scientifically?"). Because scientific knowledge concerning the past is never reliable, any view about the history of life on earth is ultimately a decision based on non-scientific beliefs. It is this choice that constitutes the framework in which further scientific reasoning is placed. Therefore the same scientific facts can result in different theories that all should have the same scientific status.

All kinds of facts can be used in both theories [evolution and creation]. One person uses it in his theory, another in his, and it both fits. For instance, the similarity between human beings and apes, there is this percentage overlap in human beings and apes. An evolutionist says: there you see, that is because we are closely related, have a common ancestor. And a creationist says: there you see, the same Creator has been at work and used the same materials, the same DNA for ape and human being. You see? Lots of things can be used in both theories like that. (R4)

This argument seems to be a pivotal point in the reasoning of the respondents. What it does is reframe the evolution-creation controversy from a science versus religion debate into either a science versus science debate (two equally justified scientific theories competing) or a religion versus religion debate (two worldviews both based on non-scientific beliefs). By placing themselves on equal grounds with proponents of evolution, they feel fully justified in choosing one theory over another.

At the heart of this reasoning lies a fundamental misunderstanding of the scientific method concerning evolution. While the theory of evolution tells the story of the past, it is based on observations and facts in the present, like fossils and DNA. It can be falsified when new facts are found. The misunderstanding lies in the ambiguity of the term repeatability. When the scientific method demands reproducibility of scientific results it does not mean, as the respondents falsely assume, that the entire evolutionary history should be repeated to qualify as science. The results therefore support a knowledge deficit concerning the scientific method as an explanation for the rejection of evolution. This will be discussed later on.

\section{Attitude towards science}

The respondents were unanimously positive about science. Sex, age and level of education and involvement with (natural) science play no role in the attitude towards science. All feel that science has contributed greatly to human welfare, mainly the medical sciences and technology. Four respondents stressed that science was given by God to develop the innate potential of creation. Four people gave remarks about negative effects of some scientific developments such as the possibility of abortion and euthanasia. But those were viewed as immoral human choices and not as a result of science itself. All agree that society is better off with science than without.

No support for an attitude deficit was found. The rejection of evolution is combined with a positive attitude towards science. This seeming inconsistency can be understood considering that the respondents do not view evolution as real science. Their problem is not with science, but with evolution, which the respondents think does not belong to science. Therefore the respondents see no problem at all in praising science while rejecting evolution. 


\section{Trust in science}

The positive attitude towards science in general extends to the trust in science exhibited by the respondents. Distrust and cynicism concerning science in general were not found. Concerning evolution, the responses are mixed. Eight of the respondents believe that evolutionary scientists are honest and sincere in their work and that their conclusions concerning evolution stem from the non-scientific assumptions in their work or from personal beliefs interfering with their work.

I think that [evolutionary scientists] are honest in their research, but that doesn't mean that I should agree to their opinion. If I would research something with honesty, they also might not agree. [...] I don't think they intend to deceive. I don't think that they sit together and say: let's deceive the public, what theory can we come up with today, no I do not think that. (R5)

Half of the respondents think that research concerning creation and research that is critical of evolution are actively kept out of journals and universities by the scientific community. Interestingly, this is mainly brought up by the respondents with a degree in the natural sciences.

In the scientific community, it is not done to provide arguments that could support God's existence. This will put you directly out of the community. [...] It's funny that scientists among each other, at an evolution convention for instance, do talk about... it is of course inexcusable that we never found a missing link. If they know there are no creationists around, they do admit that [evolution] is in trouble. (R3)

While distrust concerning scientific research and the scientific community is found, this trust deficit only concerns evolutionary science. Considering the line of reasoning that separates evolution from the rest of science by being non-scientific, this trust deficit must be regarded not as a cause, but as an effect of the rejection of evolution. When creation is believed to be as scientific as the belief in evolution, a scientific community that takes sides in this controversy is not objective and uses its power to support subjective beliefs. Every indication of non-objectivity in the scientific community then becomes proof supporting the bias of scientists towards evolution. This could be an explanation of the fact that the respondents with a degree in the natural sciences and therefore to some extent involved in the scientific community, gave the most examples of scientific bias towards evolution. They possibly know from experience that science does not always follow the ideal scientific method, and use this to suggest that support for evolution is not objective and rational, but influenced by personal beliefs.

\section{Summary and discussion}

The interviews showed saturation, with later interviews adding almost no new information. The number of interviews was therefore considered to be sufficient for an exploratory research. The results were largely independent of sex, age and religious affiliation. Level of education and education in the natural sciences showed some variation, mainly concerning the level of scientific knowledge and the amount of trust in science, with higher educated respondents with an education in the natural sciences having more knowledge and being less trustful of science. The level of homogeneity in the results might be surprising. Possibly it can be explained by the overlap in sources and authorities used by the respondents to form their opinion.

The reframing of the evolution-creation controversy in the field of public understanding of science gives insight in how the rejection of evolution by Christians relates to certain images of science. 
These images can be specified with respect to the three hypotheses, based on three paradigms in Bauer et al. (2007). A knowledge deficit concerning factual scientific knowledge about evolution was found for some of the respondents. One particular argument, claiming that evolution is not science, was used by all respondents to reframe the debate from science versus religion to religion versus religion. This argument rests on a misunderstanding of the scientific method, and can therefore be considered as a knowledge deficit. It takes a central place in the reasoning of all of the respondents, allowing them to dismiss evolution as science and therefore to maintain both their positive attitude towards science in general and their rejection of evolution. An attitude deficit was not found, all respondents were unanimously positive about science. A trust deficit was found, but was interpreted as an effect of the rejection of evolution and the reframing of the debate into a religion versus religion controversy, and not as a cause of the rejection of evolution.

All three hypotheses are not sufficient to explain the rejection of evolution by the participants. It is clear from the interviews that the decision to reject evolution is not based on scientific knowledge or certain images of science, but on non-scientific, religious beliefs. Therefore, the rejection of evolution is not grounded in certain images of science, but vice versa: the images of science themselves seem to be grounded in the rejection of evolution. For instance, the respondents do not mistrust science and therefore reject evolution, but reject evolution and therefore mistrust any science that supports evolution. Any scientific reasoning, and beliefs about evolution not being science, seem to be a support for certain Christian beliefs about the origin of the world, and not a cause of the rejection of evolution itself. The decision to reject evolution does not involve scientific knowledge. Arguments drawn from science are merely viewed as an addition to a decision that is already made and serve as a rationale to a non-rational decision.

The question could be asked why the participants reframe the evolution-creation debate into a religion versus religion (or, in some respects, science versus science) debate. Although this is not the main focus of this paper, some suggestions could be considered.

The treatment of religion and science by the respondents resembles the concept of cognitive polyphasia (Moscovici, 1976). The respondents use different levels of knowledge to think about the world. In this case, there is religious knowledge, which says that God created the world. There is also scientific knowledge, which explains the world in scientific terms. The scientific way of thinking does not replace the religious way of thinking about the world, but coexists with it. In many areas, these ways of thinking are not in conflict. But when they do overlap, as with evolution, the incompatibility of both views does not imply that one way of thinking is discarded. They are both needed: the scientific way of thinking to live in the modern world, and the religious way of thinking because it responds to needs and problems that science does not and cannot respond to (Jovchelovitch, 2008). However, this is not the end of the story. It is curious that all respondents in the interviews seem to need the scientific rationale for their non-scientific decision to reject evolution. All of them at least supported the view that evolution is not truly scientific to support their rejection of evolution. This suggests that the respondents are not entirely comfortable with the inconsistencies between the religious and the scientific modes of knowledge, and are actively looking for rational support for their religious decision to reject evolution. Considering that they all, even the scientifically trained respondents, find this in the rather dubious argument of the non-repeatability of evolution, it suggests that a knowledge deficit plays at least some role in the rejection of evolution. It seems unlikely that the respondents will embrace evolution when educated about evolution being science, and therefore it might not be a true knowledge deficit. But it shows that there is a deep-rooted urge for consistency, to make the rejection of evolution at least a little rational. 
Why this is the case, is not clear. It could be the case that it fulfils a need for reduction of cognitive dissonance (Festinger, 1957). Cognitive dissonance could be the result of holding two opposing beliefs, namely a positive attitude towards science and technology on the one hand and the rejection of an established scientific theory on the other. Isolating the rejected theory from science in general resolves that dissonance. If this is the case, the need for reduction of cognitive dissonance could make this line of reasoning irresistible, even more so for the science trained, whose cognitive dissonance is possibly even larger.

It is also possible that the intellectual theological tradition of Dutch Protestantism plays a role here. The respondents stress that evolution would seriously interfere with their religious beliefs about the infallibility of the Bible and the redemption of Jesus Christ following the Fall of Men at the historical beginning of life. If evolution creates too many inconsistencies in the theological system, the price of accepting evolution would be too high, namely the collapse of the system and ultimately losing faith. Therefore, the Dutch Protestants could be looking for different ways to maintain intellectual consistency.

Of course, additional research is needed to answer the question why Christians who reject evolution use the scientific mode of knowledge alongside the religious mode of knowledge. The religious and scientific views of Christians in this research should be compared to the views of Christians who accept evolution. The differences found could be helpful in understanding the processes that lead some Christians to reject evolution.

As for the implication for debates concerning evolution and creation, it can be concluded that a scientific discussion about the validity of evolution with Christians who reject evolution can be expected to have limited success. The initial decision to reject evolution is non-scientific and based on religious beliefs. Therefore, common ground for a scientific debate regarding evolution will be scarce. If any, debates should focus on the reframing of the evolution controversy from religion versus science into religion versus religion. As long as this issue is unfixed, any attempt to discuss the facts of evolution, improve attitudes towards science or restore trust in science, is expected to be unfruitful.

\section{Acknowledgements}

The authors would like to thank Mirjam de Groot for her methodological help.

\section{Note}

1. The interviewer was not personally acquainted with any of them.

\section{References}

Bauer MW, Allum N, and Miller S (2007) What can we learn from 25 years of PUS research? Liberating and expanding the agenda. Public Understanding of Science 16(1): 79-95.

De Hond M (2009) Darwin, wetenschap en geloof. Available at: https://n4.noties.nl/peil.nl/

De Souza RF, De Carvalho M, Matsuo T, and Zaia DAM (2010) Study on the opinion of university students about the themes of the origin of Universe and evolution of life. International Journal of Astrobiology 9: $109-117$.

Durant J (1993) What is scientific literacy? In: Durant J and Gregory J (eds) Science and Culture in Europe. London: Science Museum, pp. 129-138.

Gustafson P (2001) Meanings of place: Everyday experience and theoretical conceptualizations. Journal of Environmental Psychology 21(1): 5-16.

Festinger L (1957) A Theory of Cognitive Dissonance. Stanford: Stanford University Press. 
Francis LJ and Greer JE (1999) Attitudes towards creationism and evolutionary theory: The debate among secondary pupils attending Catholic and Protestant schools in Northern Ireland. Public Understanding of Science 8(2): 93-103.

Hayes C and Tariq VN (2000) Gender differences in scientific knowledge and attitudes toward science: A comparative study of four Anglo-American nations. Public Understanding of Science 9(4): 433-447.

Hess DJ (2011) To tell the truth: On scientific counterpublics. Public Understanding of Science 20(5): 627-641.

Jovchelovitch S (2008) The rehabilitation of common sense: Social representations, science and cognitive polyphasia. Journal for the Theory of Social Behaviour 38(4): 431-448.

Martin-Hansen LM (2008) First-year college students' conflict with religion and science. Science and Education 17: $317-357$.

Miller JD (1998) The measurement of civic scientific literacy. Public Understanding of Science 7: 203-223.

Miller JD, Scott EC, and Okamoto S (2006) Public acceptance of evolution. Science 31: 765-766.

Miller S (2001) Public understanding at the crossroads. Public Understanding of Science 10: 115-120.

Moscovici S (1976) La psychanalyse son image et son public. Paris: Presses Universitaires de France, p. 175.

National Academy of Sciences (1998) Teaching About Evolution and the Nature of Science. Available at: http://www.nap.edu/catalog.php?record_id=5787

Park HJ (2001) Carving creation in the public mind. Public Understanding of Science 10: 173-186.

Pennock RT (2004) Creationism and intelligent design. Annual Review of Genomics and Human Genetics 4: $143-163$.

Rowe G and Frewer L (2004) Evaluating public participation exercises: A research agenda. Science, Technology and Human Values 29(4): 512-556.

Rutledge ML and Warden MA (2000) Evolutionary theory, the nature of science \& high school biology teachers: Critical relationships. American Biology Teacher 62(1): 23-31.

Slovic P and Peters E (1998) The importance of worldviews in risk perception. Journal of Risk Decision and Policy 3(2): 165-170.

Stankiewicz P (2009) The role of risks and uncertainties in technological conflicts: Three strategies of constructing ignorance. Innovation: The European Journal of Social Science Research 22(1): 105-124.

SynovateBV(2009)Project90054 Evolutie of schepping? Availableat:http://www.synovate.nl/pdf/EvolutieOf Schepping.pdf

Wester F and Peters V (2004) Kwalitatieve analyse. Uitgangspunten en procedures. Bussum: Coutinho.

Wetenschappelijke Raad voor het Regeringsbeleid (WRR) (2006). Geloven in het publieke domein. Available at: http://www.wrr.nl/content.jsp?objectid=3810

Wynne B (1992) Misunderstood misunderstanding: Social identities and the public uptake of science. Public Understanding of Science 1: 281-304.

Wynne B (1993) Public uptake of science: A case for institutional reflexivity. Public Understanding of Science 2: $321-338$.

\section{Author Biographies}

Peter Hildering is head of the communication department at Centrum Wiskunde \& Informatica (CWI) in Amsterdam, The Netherlands. He graduated in physics and science communication at the Radboud University Nijmegen.

Luca Consoli is Assistant Professor of Science and Society at the Radboud University Nijmegen. His research and teaching activities focus on virtue ethics in relationship to scientific practices and the societal impact of modern science and technology.

Riyan van den Born is Assistant Professor of Science Communication at the Department of Philosophy and Science Studies at the Radboud University Nijmegen, The Netherlands. Her research focuses mainly on public perceptions and visions of nature. 